\title{
Effect of Fermented Modified Potato Starches to Low-fat Yogurt
}

\author{
Elena Nikitina*, Rifqi Ahmad Riyanto, Adel Vafina, Tatiana Yurtaeva, Maxim Tsyganov, Galina Ezhkova \\ Department of Meat and Milk Technology, Faculty of Food Technology, \\ Kazan National Research Technological University, 420015, Kazan, Russia \\ *Corresponding author: ev-nikitina@inbox.ru
}

Received June 10, 2019; Revised July 21, 2019; Accepted July 30, 2019

\begin{abstract}
The demand for dairy products globally is increasing. No exception for yogurt. As a quick and healthy drink, yogurt's consumers demand lower fat content for health reasons. yogurt loss its original texture and viscosity if the fat content is lower than normal. To resolve the issue, fat replacers are added to the low-fat yogurt. In this study we used enzymatically modified potato starch as the fat replacer. The results showed that the characteristic of low-fat yogurt with the addition of modified starch with amylosubtilin and amylase from Bacillus licheniformis are quite similar to native starch.
\end{abstract}

Keywords: low-fat yogurt, starch, fat replacer, chemical composition, structural features

Cite This Article: Elena Nikitina, Rifqi Ahmad Riyanto, Adel Vafina, Tatiana Yurtaeva, Maxim Tsyganov, and Galina Ezhkova, "Effect of Fermented Modified Potato Starches to Low-fat Yogurt." Journal of Food and Nutrition Research, vol. 7, no. 7 (2019): 549-553. doi: 10.12691/jfnr-7-7-10.

\section{Introduction}

Milk is known for its nutritional value for human. As the source of energy and also for the fulfillment of the micronutrients such as minerals and vitamins. In this age, milk is consumed not only in its original form. With the help of nature and technologies, a wide variety of dairy products can be enjoyed now. For example cheese, butter and yogurt. The demand for dairy milk products as mentioned by International Dairy Federation [1] is always increasing. In the year of 2015, global per capita dairy consumption was estimated at $111.3 \mathrm{~kg}$. According to the OECD and FAO, this number should increase $12.5 \%$ by 2025.

One of the favorite dairy products is yogurt. Yogurts are prepared by fermentation of milk with bacterial cultures consisting of a mixture of Streptococcus subsp. thermophilus and Lactobacillus delbrueckii subsp. bulgaricus. The milk solids content (including the fat content) for yogurt ranges from around $9 \%$ for skim milk yogurt to more than $20 \%$ for certain types of concentrated yogurt. Many commercial yogurt products have milk solids contents of $14-15 \%$ [2]. Consumers who concerned with the health are now demanding low or even non-fat yogurt. As the fat content loss, yogurt's sensory and organoleptics characters are also changed.

Fat solids reduction in yogurt has been associated with poor texture, where commonly the fat removed is substituted by skim milk powder, sodium caseinate, or whey protein concentrates. The amounts required of these ingredients to achieve the total solids content similar to that of the full-fat yogurt can lead to a powdery taste, excessive acid development from lactose fermentation, excessive firmness, higher whey expulsion, and grainy texture [3].

In order to receive low-fat yogurt with the same texture and consistency, usually fat replacers are added. Fat replacers are ingredients that can be incorporated into food products like chees [4], yogurt [5], and food functional ingredients [6]. Hydrocolloids (gelatin, xanthan gum, carrageenan and modified starch) effect to texture, rheology, syneresis and lubrication properties of skim potset yoghurt [7]. Here in this study we use enzymatically modified potato starch as the fat replacers. Especially the modified potato starch with the help of amylosubtilin and amylase from Bacillus licheniformis.

\section{Materials and Methods}

\subsection{Fermented Milk Preparations and Starch}

The cow's milk pasteurized (according to GOST 314502013 standard) which was subjected then to centrifugation at $3000 \mathrm{~g}$ acted as an object of a research, received milk fat content of $1,8 \%$.

The analysis of physical and chemical properties of milk tested by Milk analyzer "Klever-2M" with the method recommended by the producer (Biomer, Russia).

Strains of Lactobacillus delbrueckii subsp. bulgaricus strain 51, and Streptococcus thermophilus were used for yogurt fermentation in $37^{\circ} \mathrm{C}$ for 16 hours as the starter culture. Milk without starches was used as control, $2 \%$ by weight of starch was added to the test samples then heated with constant stirring. After cooling the milk-starch mixture starter culture was inoculated $5 \% \mathrm{v} / \mathrm{v}$. Incubation 
at $37^{\circ} \mathrm{C}$ until the $\mathrm{pH}$ reached $4.5-4$. The $\mathrm{pH}$ was measured with a $\mathrm{pH}$ meter every hour.

Native potato starch (according to GOST P52791-2007 standard) was used for the experiment. Modification of this starch was based on the application of Amylosubtilin ${ }^{\circledR}$ (AM) and Amylase from Bacillus licheniformis (Bl) of different concentrations (Table 1).

Modification was carried out in water $(30 \mathrm{~g} / 100 \mathrm{ml})$, $\mathrm{pH}=7,40^{\circ} \mathrm{C}$ for 1 hour. The hydrolysis reaction was stopped with the addition of concentrated sulfuric acid $(\mathrm{pH}=2)$. The starch was afterwards separated from the liquid by filtration and dried at $40{ }^{\circ} \mathrm{C}$. The starches were used for further research. Physicochemical and morphological characterization of potato starches modified by bacterial amylases have been described by us earlier [8].

Table 1. Code of fermented modified starches

\begin{tabular}{lccc}
\hline Starches & $\begin{array}{c}\text { Amylase } \\
\text { activity (U/g } \\
\text { starch) }\end{array}$ & $\begin{array}{c}\text { Amylosub-thilin } \\
\text { (g/100 ml reaction } \\
\text { mixture) }\end{array}$ & $\begin{array}{c}\text { Amylase } B . \\
\text { licheniformis } \\
\text { (ml/100 ml reaction } \\
\text { mixture) }\end{array}$ \\
\hline AM-0.05 & 0.415 & 0.01 & - \\
AM-0.1 & 0.83 & 0.0201 & - \\
AM-0.05 & 4.15 & 0.1005 & - \\
AM-1 & 8.3 & 0.201 & - \\
Bl-0.05 & 0.415 & - & 0.05 \\
Bl-0.1 & 0.83 & - & 0.1 \\
Bl-0.5 & 4.15 & - & 0.5 \\
Bl-1 & 8.3 & - & 1 \\
\hline
\end{tabular}

\subsection{Quantitative Chemical Analysis of Yogurts}

Analysis of protein, fat, carbohydrates, density and solids of the yogurt was performed on the InfraLUM ${ }^{\circledR}$ FT-12 (Russian Federation) with appropriate software and calibration data for the product "yogurt".

Acidity Analysis. pH measurements were carried out by using a digital $\mathrm{pH}$ meter (HI 2216, Hanna Instruments, Germany).

The titratable acidity in homemade yogurt was estimated by titration a suspension (10 g yogurt in $20 \mathrm{ml}$ distilled water). The samples was boiled to drive off the carbon dioxide and cooled. The sample then was titrated with $0.1 \mathrm{M}$ sodium hydroxide $(\mathrm{NaOH})$ to pink color in the presence of $1 \%$ of phenolphthalein as indicator and expressed as percent lactic acid. Lactic acid (mmol/g product) is calculated as follow:

$$
\text { Lactic acid }=\frac{m l \text { of alkali } x \text { Normality of alkali }}{\text { Weight of sampling }} \times 0.9 \text { (1) }
$$

Water holding capacity (WHC) and syneresis analysis [9]. Samples of fermented milk (about 20 g) (Y) after cooling to $+4{ }^{\circ} \mathrm{C}$ in 24 hours of storage were centrifuged for 10 minutes at $3000 \mathrm{rpm},+20^{\circ} \mathrm{C}$. The released serum (W) was removed and weighed. The Water-holding capacity of fermented milk is calculated by formula:

$$
W H C=(Y-W) / Y \times 100 \% .
$$

Syneresis was measured after samples (about $20 \mathrm{~g}$ ) were cooled to $+4^{\circ} \mathrm{C}$ in 24 hours of storage (Y). Samples were centrifuged for 5 minutes, $500 \mathrm{rpm}$ in $+20^{\circ} \mathrm{C}$. The released serum (S) was removed and weighed. Syneresis of fermented milk is calculated by the formula:

$$
\text { Syn }=S / Y \text {. }
$$

The results are in grams of water/100 g of the product.

Viscosity Measurement. The viscosity was determined from the time of expiration of the yogurt from a $25 \mathrm{ml}$ pipette with an internal diameter of the outlet $5 \mathrm{~mm}$ and expressed in seconds. The test is carried out at a temperature of $20^{\circ} \mathrm{C}$.

Sensory Evaluation. Yogurt samples were evaluated by panelist. A hedonic scale of 1 (extremely dislike) to 10 (like extremely) was used for flavor, 1 (poor) to 3 (excellent) for odour, 1 (poor) to 10 (excellent) for texture and consistency, and 1 for the yogurt appearance. Defects were also asked if any detected. Each participant received $30 \mathrm{ml}$ yogurt (at $12^{\circ} \mathrm{C}$ ) in a 100 -ml glass vial with a twistoff lid.

The color parameters $\left(\mathrm{L}^{*}, \mathrm{a}^{*}\right.$, and $\left.\mathrm{b}^{*}\right)$ of the yogurt samples were measured using a colorimeter Chroma Meter (China) [10]. Different values represent different colors: $\mathrm{L}^{*}$,darkness-lightness $(0-100) ; \mathrm{a}^{*}$, greennessredness $(-60-+60)$; $b^{*}$, blueness-yellowness $(-60-+60)$. Yogurt samples $(50 \mathrm{ml})$ were stirred and placed in an aluminium cylinder (outside diameter $55 \mathrm{~mm}$ ), with the surface optically flat before measuring, and the sensor was mounted directly on top of the cylinder to prevent ambient light noise.

\subsection{Statistical Analysis}

All experimental data were obtained as a result of at least three parallel experiments, the results of analytical determinations for each sample in two or three parallel experiments. The tables and figures showed data from typical experiments, each value being the average of three to five determinations. Only those results that were reproducible in each experiment are discussed.

\section{Results and Discussion}

\subsection{Chemical composition}

The chemical composition of yogurts with different fatreplacers is shown below in Table 2. The total solids, protein, whey protein, and fat contents in all treatments ranged between 10.8 and $12.5 \% ; 4.2$ and $4.4 \%$; 3.0 and $3.2 \% ; 1.7$ and $1.8 \%$ respectively.

For example, whereas AM-1 and Bl-1 had approximately the same solids content, protein and whey protein. The highest total solids for treatment was founded in AM-0.5 yogurt while the lowest in Bl-0.05.

Compared to the control, all treatments had higher total solids percentage but still lower than the native. The highest protein content was detected also in AM-0.5 with the percentage of 4.38 while the lowest also in $\mathrm{Bl}-0.05$ with $4.19 \%$ protein.

Whey protein content were detected in the highest content within Bl-1 treatment while the lowest in Bl-0.1 treatment. Highest carbohydrates content was found in AM-0.1 treatment and native with $6.98 \%$ while the lowest 
in control with $4.85 \%$. Carbohydrates and solids in experimental samples are increased by adding $2 \%$ starch. Generally, all the treatments resulted in low-fat yogurts had higher total solids and in accordance with the Codex Standard for Fermented Milk, which contained minimum $4 \%$ of protein [11].

Table 2. Chemical composition of yogurt from various fat-replacers

\begin{tabular}{cccccc}
\hline $\begin{array}{c}\text { Reduced-Fat } \\
\text { yogurt } \\
\text { Code }^{1}\end{array}$ & $\begin{array}{c}\text { Total } \\
\text { Solids } \\
(\%)\end{array}$ & $\begin{array}{c}\text { Protein } \\
(\%)\end{array}$ & $\begin{array}{c}\text { Whey Protein } \\
(\%)\end{array}$ & Fat (\%) & $\begin{array}{c}\text { Carbo } \\
\text { hydrates } \\
(\%)\end{array}$ \\
\hline Control & $10.8 \pm 0.1$ & $4.3 \pm 0.1$ & $3.0 \pm 0$ & $1.88 \pm 0.4$ & $4.85 \pm 0.2$ \\
Native & $12.8 \pm 0.2$ & $4.4 \pm 0.1$ & $3.2 \pm 0.1$ & $1.81 \pm 0.3$ & $6.98 \pm 0.3$ \\
AM-1 & $12.5 \pm 0.3$ & $4.3 \pm 0.2$ & $3.1 \pm 0.1$ & $1.85 \pm 0.2$ & $6.96 \pm 0.04$ \\
AM-0.5 & $12.7 \pm 0.3$ & $4.4 \pm 0.1$ & $3.1 \pm 0.2$ & $1.81 \pm 0.1$ & $6.76 \pm 0.2$ \\
AM-0.1 & $12.2 \pm 0.2$ & $4.2 \pm 0.1$ & $3.1 \pm 0.1$ & $1.81 \pm 0.2$ & $6.98 \pm 0.2$ \\
AM-0.05 & $12.5 \pm 0.3$ & $4.3 \pm 0.2$ & $3.1 \pm 0.1$ & $1.81 \pm 0.2$ & $6.01 \pm 0.1$ \\
Bl-1 & $12.5 \pm 0.4$ & $4.3 \pm 0.2$ & $3.2 \pm 0.2$ & $1.86 \pm 0.3$ & $6.04 \pm 0.04$ \\
Bl-0.5 & $12.5 \pm 0.2$ & $4.3 \pm 0.1$ & $3.1 \pm 0.1$ & $1.77 \pm 0.4$ & $6.05 \pm 0.1$ \\
Bl-0.1 & $12.2 \pm 0.1$ & $4.2 \pm 0.1$ & $3.0 \pm 0$ & $1.89 \pm 0.2$ & $6.94 \pm 0.2$ \\
Bl-0.05 & $12.1 \pm 0.4$ & $4.2 \pm 0.2$ & $3.0 \pm 0.2$ & $1.84 \pm 0.3$ & $6.88 \pm 0.5$ \\
\hline
\end{tabular}

${ }^{1}$ For yogurt codes, see Table 1.

\subsection{Acidity Analysis}

This parameter is considered as control to measure the fermentation time. The changes of $\mathrm{pH}$ before and after the cooling step indicate the activity of the initiator culture and its capacity to produce lactic acid from the lactose. Yogurts' $\mathrm{pH}$ and titrable acidity results are shown in Figure 1 below. Compared with the control, all the treatments except Bl-0.5 were resulted in $\mathrm{pH}$ below 4.5 .

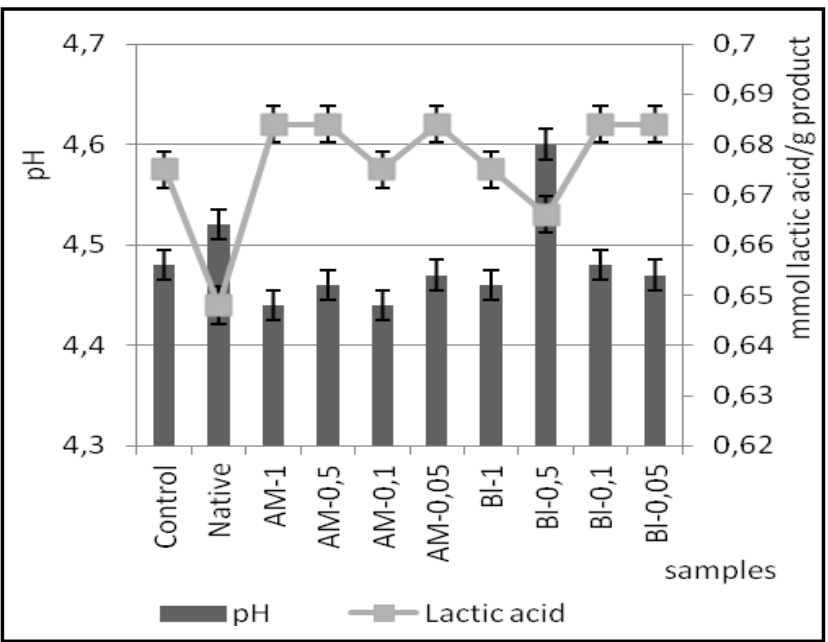

Figure 1. Acidity analysis of yogurt from various fat-replacers

The titrable acidity level also ranged between 0.666 to $0.684 \mathrm{mmol}$ lactic acid/g product. The lowest $\mathrm{pH}$ was founded in treatment A-1 and A-0,1 with the $\mathrm{pH}$ of 4.44 and the highest $\mathrm{pH}$ in $\mathrm{B}-0,5$ with the $\mathrm{pH}$ of 4.6 . Lactic acid concentration was found the lowest in B-0,5 also with $0.666 \mathrm{mmol}$ lactic acid/g product. This correlated with the carbohydrate (lactose) content of the B-0,5 treatment from previous chemical composition data in Table 2. It had the lowest content of lactose. Compared to native, all treatments generally have better performance in producing lower $\mathrm{pH}$ and higher lactic acid concentrations.

\subsection{Textural Characteristic}

The texture of yogurt mainly depends on the content of protein and fat in yogurt. AM-0.1 exhibited the lowest syneresis with the value of $8.41 \mathrm{~g}$ water/100 $\mathrm{g}$ product while Bl-0.1 showed the highest syneresis level with the value of $10.43 \mathrm{~g}$ water/100 g product (Table 3 ). We found that all the treatments gave higher syneresis and only A-0,1 treatment gave lower syneresis than native. The most important causes for syneresis in fermented products include the use of high temperatures of incubation, low solids content or inadequate storage temperatures [12].

Viscosity is one of the major parameters for research in semiliquid food products [13]. Some authors have indicated that smoothness is a highly desirable sensory characteristic in food emulsions such as dairy products. Smoothness can be related to creaminess and thickness, which depends on the viscosity. The highest viscosity was detected in treatment AM-0.5 with the value of $3.2 \mathrm{sec}$ and the lowest in treatment $\mathrm{Bl}-0.05$ with the value of $2.3 \mathrm{sec}$.

Then the WHC of all treatments not really differ much. The lowest WHC was founded in A-1 with $32.83 \%$ and the highest in B-1 with $33.39 \%$. Compared to the native, WHC percentage was lower in all treatments. This also applied in viscosity which only A-0,5 value gave near the same viscosity value as the native.

It has been postulated that the fat-mimicking properties of starch granules result from the association of water-carbohydrate molecules and association of the released linear amylose molecules, which can give rise to viscosity increases and gelation [14]. Oh and others (2007) [15] also reported that with the addition of starch the protein network remained as a continuous dominant phase.

Table 3. Textural characteristic of yogurt from various fat-replacers

\begin{tabular}{c|c|c|c}
\hline $\begin{array}{c}\text { Reduced-Fat } \\
\text { yogurt Code }\end{array}$ & $\begin{array}{c}\text { Syneresis } \\
\text { (g water/100g } \\
\text { product) }\end{array}$ & WHC (\%) & Viscosity (s) \\
\hline Control & $11.4 \pm 2.5$ & $33.1 \pm 2.5$ & $2.75 \pm 0.5$ \\
\hline Native & $8.6 \pm 3.1$ & $35.8 \pm 3.6$ & $3.30 \pm 0.6$ \\
\hline AM-1 & $10.7 \pm 3.5$ & $32.8 \pm 2.4$ & $2.65 \pm 0.6$ \\
\hline AM-0.5 & $9.7 \pm 2.1$ & $33.2 \pm 1.8$ & $3.20 \pm 0.5$ \\
\hline AM-0.1 & $8.4 \pm 2.5$ & $33.3 \pm 2.5$ & $2.80 \pm 1$ \\
\hline AM-0.05 & $10.1 \pm 2.5$ & $33.2 \pm 2.9$ & $2.60 \pm 0.9$ \\
\hline Bl-1 & $9.4 \pm 2.1$ & $33.4 \pm 1.9$ & $2.45 \pm 0.6$ \\
\hline Bl-0.5 & $9.2 \pm 0.9$ & $33.1 \pm 2.3$ & $2.75 \pm 0.6$ \\
\hline Bl-0.1 & $10.4 \pm 1.2$ & $32.9 \pm 2.4$ & $2.45 \pm 0.9$ \\
\hline Bl-0.05 & $8.8 \pm 1.3$ & $33.2 \pm 1.9$ & $2.30 \pm 0.9$ \\
\hline
\end{tabular}

\subsection{Sensory Evaluation}

Table 4 showed the sensory evaluation of all the yogurt treatments. The sensory analysis showed that attributes such as Appearance did not differ between the yogurt samples (Table 4). From the results, all of the treatments had better consistency than the control.

Also the odour and flavor were the same or better than control, except for B-0,5 yogurt. The best flavor was in B-0,1 treatment. 
Table 4. Sensory evaluation of yogurt from various fat-replacers

\begin{tabular}{c|c|c|c|c}
\hline $\begin{array}{c}\text { Reduced-Fat } \\
\text { yogurt code }\end{array}$ & Appearance & Consistency & Odour & Flavor \\
\hline Control & 1 & 7 & 3 & 6 \\
\hline Native & 1 & 6 & 3 & 6 \\
\hline AM-1 & 1 & 8 & 2 & 6 \\
\hline AM-0,5 & 1 & 8 & 3 & 7 \\
\hline AM-0,1 & 1 & 8 & 3 & 6 \\
\hline AM-0,05 & 1 & 8 & 2 & 6 \\
\hline Bl-1 & 1 & 8 & 3 & 7 \\
\hline Bl-0,5 & 1 & 8 & 2 & 5 \\
\hline Bl-0,1 & 1 & 8 & 2 & 8 \\
\hline Bl-0,05 & 1 & 8 & 3 & 6 \\
\hline
\end{tabular}

Yogurts with starches AM-0.5, Bl-1 and Bl-0.1 have the highest total scores, according to the testers have a balanced taste and aroma (Figure 2).

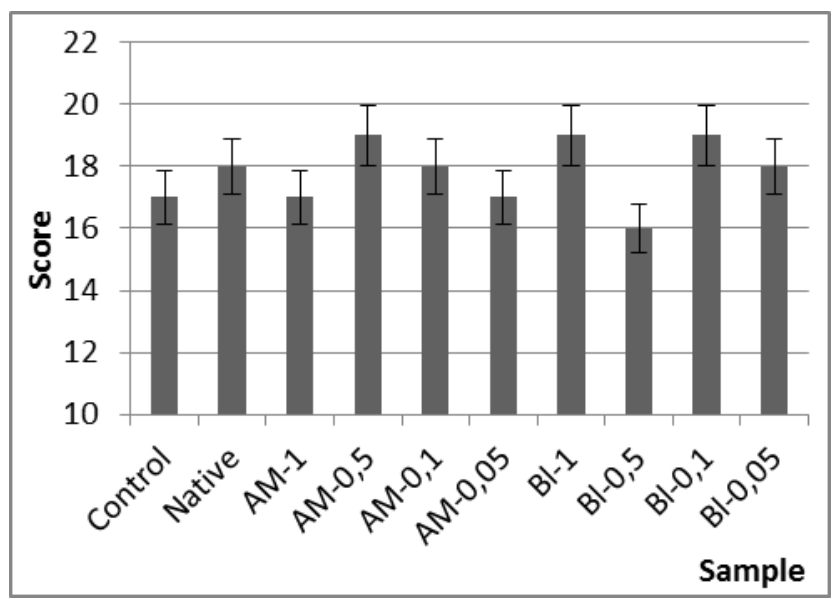

Figure 2. Total sensory score of yogurts from various fat-replacers

Color is one of the most important visual attributes in dairy products. Comparison of $\mathrm{L}, \mathrm{a}, \mathrm{b}$ and $\mathrm{C}$ values shows color differences among the yogurts (Table 5).

Table 5. The color value of yogurts

\begin{tabular}{c|c|c|c}
\hline Reduced-Fat yogurt code & $\mathrm{L}$ & $\mathrm{a}$ & $\mathrm{b}$ \\
\hline Control & $100 \pm 0$ & $-9.3 \pm 2.3$ & $30.9 \pm 3.1$ \\
\hline Native & $100 \pm 0$ & $-4.8 \pm 6.2$ & $11.1 \pm 2.8$ \\
\hline AM-1 & $100 \pm 0$ & $-8.6 \pm 3.2$ & $18.8 \pm 4.1$ \\
\hline AM-0.5 & $100 \pm 0$ & $-6.1 \pm 4.1$ & $15.3 \pm 3.9$ \\
\hline AM-0.1 & $100 \pm 0$ & $-8.6 \pm 1.3$ & $22.2 \pm 2.3$ \\
\hline AM-0.05 & $100 \pm 0$ & $-5.9 \pm 2.3$ & $14.9 \pm 3.1$ \\
\hline Bl-1 & $100 \pm 0$ & $-4.6 \pm 4.1$ & $11.2 \pm 2.3$ \\
\hline Bl-0.5 & $100 \pm 0$ & $-5.8 \pm 1.9$ & $12.7 \pm 3.1$ \\
\hline Bl-0.1 & $100 \pm 0$ & $-8.3 \pm 2.9$ & $31.0 \pm 4.1$ \\
\hline Bl-0.05 & $100 \pm 0$ & $-11.1 \pm 2.9$ & $26.7 \pm 4.3$ \\
\hline
\end{tabular}

Starch-stabilized and control yogurt had same L. However, most stabilized yogurts have the lower $a$ and $b$ value than control. The Bl-0.1-yoghurt had colorimetric characteristics like control yogurt.

\section{Conclusion}

Yogurt fermentation involves the conversion of lactose to lactic acid by bacteria, reducing the $\mathrm{pH}$ to 4.6. Use of modified potato starches as fat-replacers in low-fat yogurts produced positive effects to varying degrees including the producing of lactic acid. A wide range of physical textures to meet consumers' expectations could be obtained in yogurt by using different modification of potato starches. This study showed that the characteristics of yogurt formulated with modified potato starch of amylosubtilin and amylase are similar to those of native potato starch formulated yogurt; therefore, this can be used as an alternative in a low-fat yogurt.

\section{References}

[1] International Dairy Federation. THE WORLD DAIRY SITUATION 2016. (Bulletin of the International Dairy Federation 485/2016. ISSN 0250-5118. 2016.

[2] Tamime, A. Y. and Robinson, R. K. Yogurt: Science and Technology. 2nd edn. CRC Press, Boca Raton, FL. 1999.

[3] Sandoval-Castilla, O., Lobato-Calleros, C., Aguirre-Mandujano, E. and Vernon-Carterb, E.J. "Microstructure and texture of yogurt as influenced by fat replacers", Int Dairy J, 14, 2, 151-159, 2004.

[4] Diamantino, V.R., Costa, M.S., Taboga, S.R., Vilamaior, P.S.L., Franco, C.M.L. and Penna, A.L.B. "Starch as a potential fat replacer for application in cheese: Behavior of different starches in casein/starch mixtures and in the casein matrix", Int Dairy J, 89, 129-138, 2019.

[5] Kanning, M.W., de Velde, F., Alting, A.C., Mulleners, L., Sein A., van den Akker-Bleumink, B. and Buwalda, P. "Improved creaminess in stirred yoghurt through amylomaltase-treated starch domains", Int Dairy J, 27, 1-2, 86-91, 2012.

[6] Lua X., Chen J., Guo, Z., Zheng, Y., Rea, M. C., Su, H., Zheng, X., Zheng, B. and Miao, S. "Using polysaccharides for the enhancement of functionality of foods: A review", Trends in Food Science \& Technology, 86, 311-327, April 2019.

[7] Nguyen, P.T.M., Kravchuk, O., Bhandari, B. and Prakash, S. "Effect of different hydrocolloids on texture, rheology, tribology and sensory perception of texture and mouthfeel of low-fat pot-set yoghurt", Food Hydrocolloids, 72, 90-104, 2017.

[8] Vafina, V., Proskurina, V., Vorobiev, V., Evtugin, V., Egkova, G. and Nikitina, E. "Physicochemical and Morphological characterization of potato starch modified by bacterial amylases for food industry applications", Journal of Chemistry, 8, 2018. [Online]. Available:

https://www.hindawi.com/journals/jchem/2018/1627540/ [Accessed November, 2018].

[9] Omojola, M.O., Akinkunmi, Y.O., Olufunsho, K.O., Egharevba, H.O., Martins, E.O., "Isolation and physico-chemical characterization of cola starch", "African Journal of food, agriculture, nutrition and development", 10, 7, 2884-2900, 2010.

[10] Cappato, L.P., Ferreira, M.V.S., Pires, R.P., Cavalcanti, R.N., Bisaggio, R.C., Freitas, M.Q., Silva, M.C. and Cruz, A.G. "Whey acerola-flavoured drink submitted ohmic heating processing: Is there an optimal combination of the operational parameters?" Food Chemistry, 245, 22-28, 2018.

[11] CODEX STANDARD FOR FERMENTED MILKS. CODEX STAN 243-2003.

[12] Lee, W.J. and Lucey, J.A. "Formation and physical properties of yogurt,” Asian-Australasian Journal of Animal Sciences, 23, 9, 1127-1136, 2010.

[13] Dobraszczyk, B.J. and Vincent, J.F.V. Measurement of mechanical properties of food materials in relation to texture: The materials approach. In A. J. Rosenthal (Ed.), Food texture. Maryland: Aspen. 1999, 99-149.

[14] Yackel, W. C. and Cox, C. "Application of starch-based fat replacers", Food Technology, 46, 6, 146-148, 1992. 
[15] Oh, H.E., Wong, M., Pinder, D.N., Hemar, Y. and Anema, S.G. "Effect of $\mathrm{pH}$ adjustment at heating on the rheological properties of acid skim milk gels with added potato starch", Int Dairy J. 17, 1384-1392, 2007. 